\title{
Partial replacement of ryegrass and clover herbage with chicory alters urination behaviour and soil nitrogen loading of grazing dairy cows
}

\author{
MANCOBA C. MANGWE ${ }^{1,2^{*}}$ and RACHEAL H. BRYANT ${ }^{1}$ \\ ${ }^{1}$ Faculty of Agriculture and Life Sciences, Lincoln University, New Zealand \\ ${ }^{2}$ Department of Animal Science, University of Eswatini, Eswatini \\ *Corresponding author: manqoba.mangwe25@gmail.com
}

\begin{abstract}
Chicory (Chicorum intybus L.) is a high moisture, low fibre forage with the potential to alter urinary nitrogen (N) excretion. The following study compared the effect of replacing ryegrass/clover (Lolium perenne L./Trifolium repens L.; RGWC) with chicory in the diet, and the impact of diurnal changes in composition of chicory on urination frequency and volume and nitrogen (UN) concentration. Thirty-six, mixed-age dairy cows in $2^{\text {nd }}$ to $4^{\text {th }}$ parities were stratified according to days in milk (155 \pm 3.3 days), body weight (483 \pm $13.8 \mathrm{~kg})$ and milk yield $(21.3 \pm 0.97 \mathrm{~kg} / \mathrm{cow} /$ day $)$ and assigned to one of three diets. The diets were either RGWC, RGWC replaced with $50 \%$ chicory either in the morning (CHAM) or in the afternoon (CHPM). Chicory inclusion increased urination frequency by up to $69 \%$, with a $33 \%$ decline in UN concentration, independent of time of feeding. The ratio of nonstructural carbohydrates to protein was greater for CHPM compared with CHAM or RGWC diets, though offering chicory in the morning was more likely to reduce urinary $\mathrm{N}$ loss. High moisture forages such as chicory can be used to reduce urinary $\mathrm{N}$ load by increasing the spatial distribution of urine from cows.
\end{abstract}

Keywords: Urination, frequency, nitrogen, leaching, forages

\section{Introduction}

One of the key aspects of the environmental challenge associated with ryegrass and clover pasture (Lolium perenne L./Trifolium repens $\mathrm{L}$;; RGWC) in temperate regions such as New Zealand is the high crude protein (CP) concentration in the herbage, which frequently exceeds nutritional requirements of high producing dairy cows (Bryant et al., 2019). When consumed, the high protein diet results in over sixty percent of the consumed nitrogen $(\mathrm{N})$ being excreted in the urine and faeces, presenting an environmental challenge (Kebreab et al., 2001). Stock urine is one of the major sources of $\mathrm{N}$ responsible for degrading the nearby natural water bodies (Wachendorf et al., 2005). This is mainly because the $\mathrm{N}$ deposited in urine patches (200 to $2000 \mathrm{~kg} / \mathrm{ha} \mathrm{N}$ (Selbie et al., 2015)) is often at a rate that is too high for plants to utilise, resulting in accumulation of nitrate in the soil and, ultimately, $\mathrm{N}$ leaching when drainage occurs (Wachendorf et al., 2005). Consequently, strategies are being explored to attenuate $\mathrm{N}$ losses to achieve regulatory limits (Bryant et al., 2019).

Incorporation of plantain (Plantago lanceolata L.) in mixed sward pastures or grazed as a specialist crop has been proposed as a means to reduce $\mathrm{N}$ losses from soil through altering urination. Plantain is a high moisture, low fibre forage providing high fermentable energy, along with plant secondary compounds (PSC) and can reduce urinary nitrogen (UN) excretion (Minnee et al. 2020). Although the presence of PSC have shown to reduce microbial protein degradation in vitro (Navarette et al 2016), there are no direct links between PSC and reduced UN excretion. Studies to date point towards modes of action relating to the moisture content of forages reducing UN load through dilution of urine, along with improved supply of readily fermentable energy relative to protein, which has been associated with reduced urinary $\mathrm{N}$ excretion (Bryant et al., 2017, Minnee et al., 2020, Nkomboni et al., 2021)although adoption and regulation requires knowledge of the minimum amount of forage area or diet quantity to observe an effect. Aims: A grazing study was conducted to evaluate the effect of offering increasing proportions of spatially adjacent plantain (PL.

Recently the environment regulatory tool, OverseerFM, has been revised to include plantain and a series of assumptions relating to changes in UN load, and $\mathrm{N}$ partitioning into dung to predict farm level $\mathrm{N}$ loss (Shepherd 2020). From a practical perspective, additional strategies which are adoptable would provide farmers with flexibility to improve their systems by reducing $\mathrm{N}$ losses. Consequently identifying forage based modes of action for reduced UN load is likely to provide greater confidence and adoption of mitigation strategies. Forage attributes, such as rumen synchrony of energy and protein supply and high moisture, which might contribute to lower UN loading were proposed by Bryant et al. (2019) which acknowledged that both plantain and chicory (Chicorum intybus L.) possess similar characteristics. Evidence of the efficacy of these modes of action was provided by Minnee et al. (2020) when feeding plantain at increasing proportions 
in a ryegrass diet. Similarly, Mangwe et al. (2019) summer dry conditions can reduce feed availability and quality, and limit milk production. This study reports the effects of including high nutritive value, drought tolerant forbs, chicory (Cichorium intybus L. reported that sole diets of chicory increased urination frequency and diluted the concentration of $\mathrm{N}$ in the urine in the same way as plantain.

While the impacts of feeding $100 \%$ chicory on urination frequency and UN concentration have been quantified in a previous study (Mangwe et al., 2019) it is less likely that farmers can practically feed animals $100 \%$ chicory for extended periods. There may be an additional opportunity to manage chicory to reduce $\mathrm{N}$ loss through utilising diurnal changes in herbage protein and carbohydrate (Box et al., 2017). The purpose of this research was to determine the effect of chicory in a pasture-based diet, and the impact of diurnal changes in its chemical composition on urination frequency, daily urine volumes, volume per event and $\mathrm{N}$ use efficiency (NUE). The central hypothesis was that offering $50 \%$ of the diet as chicory would reduce urinary load from lactating dairy cows and whether timing access to chicory would optimise energy and protein supply further reduce UN load per urination event.

\section{Materials and Methods}

This study was carried out at the Lincoln University Research Dairy Farm, Canterbury, New Zealand between 10 December 2018 and 25 January 2019 (Lincoln University Animal Ethics Committee \#201848).

The current experiment was part of a larger study investigating the impact of chicory feeding on urination and milk composition of dairy cows. Consequently, a more detailed overview of the study's materials and methods can be found in an earlier publication (Mangwe et al., 2020). Briefly, the current experiment was a replicated factorial design, with three grazing treatments and three replicates of four cows. Grazing treatments were perennial ryegrass/white clover only [(Lolium perenne L./Trifolium repens L.; (RGWC)]; ryegrass/white clover plus morning allocation of $50 \%$ chicory (CHAM); ryegrass/white clover + afternoon allocation of $50 \%$ chicory (CHPM). Thirty-six mixedage dairy cows in their $2^{\text {nd }}$ to $4^{\text {th }}$ parities were stratified according to days in milk ( $155 \pm 3.3$ days), mean body weight $(483 \pm 13.8 \mathrm{~kg})$ and milk yield $(21.3 \pm 0.97 \mathrm{~kg} /$ cow/day) and assigned to one of the three replicated (n = 3) feeding regimes (RGWC, CHAM, and CHPM). Therefore, there were twelve cows per treatment, with four cows per group.

Cows on RGWC only were fed the new RGWC forage (34 $\mathrm{kg}$ dry matter (DM) per cow) after each morning milking. Cows on CHAM were fed a new chicory $(\mathrm{CH})$ forage (17 kg DM per cow) after morning milking and a new RGWC forage (17 kg DM per cow) after afternoon milking. Cows on CHPM were fed the new RGWC forage (17 kg DM per cow) after morning milking and a new chicory forage (17 kg DM per cow) after afternoon milking. Cows on CHPM were moved back to RGWC forage at $2130 \mathrm{hrs}$ to ensure that all cows on $\mathrm{CH}$ treatments spent equal access time $(5 \mathrm{~h})$ to chicory forage. All cows were milked twice daily, at around 0700 and $1400 \mathrm{~h}$ in an automated system (DeLaval Alpro Herd Management System, DeLaval, Tumba, Sweden). During milking, on days 6, 8 and 11, milk samples were collected from each cow during the $\mathrm{AM}$ and PM milking for milk urea nitrogen (MUN) determination. The MUN was then determined on skimmed milk by an automated Modular P analyser (Roche/Hitachi; Talke and Schubert 1965).

Pre-grazing forage samples were collected to ground level before the cows were moved onto their new allocations AM and PM $(0700 \mathrm{~h}$ and $1300 \mathrm{~h}$, respectively) on days 6,8 and 11 of the study. The RGWC treatment provided only AM samples, while the two chicory treatments had both AM and PM samples. Post-grazing samples were collected to ground level the following morning after each grazing event during sampling days. Collected samples were composited and subsampled for botanical and chemical analysis. An extensive range of data has been presented in a previous paper (Mangwe et al., 2020), including DM, nonstructural carbohydrates (NSC) and N concentration (CP/6.25). The DM content of the composited samples was determined immediately by recording fresh and dry weight after oven drying at $60^{\circ} \mathrm{C}$ for $48 \mathrm{~h}$. The $\mathrm{N}$ content was determined using near-infrared spectrophotometry (NIRS, Model: FOSS NIRSystems 5000, Maryland, USA). The NIRS calibration for $\mathrm{N}$ concentration (Variomax CN Analyser, Elementar) were previously derived from RGWC and chicory forages and were within the calibration range. The NSC was calculated as; $\mathrm{NSC}=(100-(\mathrm{NDF}+\mathrm{CP}+$ Fat + Ash $))$.

Apparent $\mathrm{N}$ intake per cow per day was estimated by multiplying the pre- and post-forage mass by the $\mathrm{N}$ content of the pre- and post-graze forage. Water troughs in each paddock were fitted with flow meters to record daily water intake for each group.

Lincoln University PEETER V1.0 sensors were used to measure urination behaviour of the cows. Details of the design of the sensor and attachment to cows have been previously outlined (Mangwe et al., 2019) milk production and $\mathrm{N}$ use efficiency, of cows grazing chicory, plantain, or ryegrass (Lolium perenne L.. Briefly, the urine sensor recorded the timing and urine volume of every urination event. As a result, volume per event, frequency and daily urine output were recorded for individual cows. Urination behaviour was 
measured daily from six cows per treatment over two runs between days 7 and 13 of the study. At least one cow per group wore the sensor during each run. In the first run (days 7 to 9), sensors were attached to three random cows per treatment, immediately after morning milking. The sensors remained on the cows until the afternoon milking of day 9 of the study. Urine sensors were again attached to a different set of three cows per treatment following the morning milking on day 10 and were removed following the morning milking on day 13. Sensors were monitored during milking, and rechargeable batteries were replaced after 36 hours. To minimise time spent in the yard when replacing batteries, sensors were detached during milking and re-attached immediately after milking. A harness was removed if it showed signs of becoming detached and was attached to another cow in the same treatment group. Only cows with a complete set of $24 \mathrm{~h}$ data were considered for statistical analysis. Consequently, a complete set of $72 \mathrm{~h}$ data was collected from seven cows (two from RGWC, three from CHAM and two from CHPM) and another set of $24 \mathrm{~h}$ data was collected from eight cows during the study (two from RGWC, three from CHAM and three from CHPM). Lying/ standing periodically triggered a recorded event. To manage non-urine events, any consecutive data with short time intervals $(<5 \mathrm{~min})$, or short duration $(<5$ s), were excluded. Similarly, events with a flat pressure curve were excluded (Shepherd et al., 2017; Mangwe et al., 2019).

Spot urine and dung samples were collected from all 36 cows following the morning and afternoon milking on days 6 and 9 of the study. Additional urine samples were collected from nine cows (three cows per treatment) at four-hourly intervals starting from 0400 to $2400 \mathrm{~h}$ on days 13 and 15 of the study. Total daily UN excretion was estimated based on UN concentration from four hourly spot samples of the nine cows, and the total urine volume from the $4 \mathrm{~h}$ preceding the spot sampling on days 6 and 9 .

Urine samples were collected by manual stimulation of the area beneath the vulva while dung was collected via rectal grab. The procedure took approximately 50 min between leaving and returning to designated paddocks. Faecal samples were frozen at $-20^{\circ} \mathrm{C}$ immediately after collection, while urine samples were acidified with sulphuric acid to prevent $\mathrm{N}$ volatilisation and stored at $-20^{\circ} \mathrm{C}$ pending further analysis. The stored faecal and urine samples were analysed for $\mathrm{N}$ concentration by combustion (Vario MAX CN, Elementar Analysensysteme, Hanau, Germany). Urine urea concentration was determined using a commercial enzymatic kinetic technique (Randox, Crumlin, Co., Antrim, UK). Creatinine concentration was determined by the Jaffe method (Daytona RX Clinical Analyser,
Randox, Nishinomiya, Japan). Ammonia concentration was determined enzymatically by Randox Daytona analysis, following the manufacturer's instructions.

\section{Statistical analysis}

All data were analysed using R (R Core Team 2018). Animal group was used as the experimental unit for all statistical analysis. Milk urea nitrogen, urine and faeces data for spot samples collected from all 36 cows were analysed using the mixed-effects model in $\mathrm{R}$ in the lme4 package version 1.1-21 of R (Bates et al., 2015). The models contained treatments (CHAM, CHPM, and RGWC) as fixed effects, while animals nested per sampling day were used as the random effect. For urine samples taken at $4 \mathrm{~h}$ intervals, grazing regime was included as fixed effect, sampling time $(0400$, $0800,1200,1600,2000,2400 \mathrm{~h}$ ) as a repeated measure and sampling day as a random effect. To determine the effects of feeding regime on daily urination patterns (time between urination events/cow, total number of urination frequency per day, total urine volume/cow/ day and urine volume/event) cows with a minimum set of 24-hour data were selected. The models contained treatment as a fixed effect while animals nested on sampling days (day in this case refers to a 24-hour cycle) were used as a random effect. Means were separated using the 'emmeans' package of R. The significant differences were tested by the Tukey posthoc test $(\mathrm{P}<0.05)$.

\section{Results}

\section{Nitrogen utilisation}

The average $\mathrm{CP}$ concentration of pre-grazed chicory was low, at $13.4 \% \mathrm{CP}$ DM compared with $15.8 \% \pm 0.9 \% \mathrm{CP}$ DM in RGWC herbage $(\mathrm{P}=0.095)$. The concentration of NSC and the ratio of NSC to CP was highest for the chicory diets and lowest for RGWC (Table 1). In spite of differences in $\mathrm{CP}$ in the herbage, variation in daily DM intake resulted in statistically similar apparent $\mathrm{N}$ intake (Table 1; $623 \pm 36.5 \mathrm{~g} /$ cow/day; $\mathrm{P}=0.151$ ). Daily milk N output (g/cow/day) and NUE (g/g N eaten) were highest for cows on CHPM, intermediate for cows on CHAM and lowest for cows on RGWC $(\mathrm{P} \leq 0.03)$. Cows offered chicory had $21 \%$ lower $(\mathrm{P}<0.001)$ MUN than the control cows, regardless of time of chicory feeding. Total estimated daily UN excretion was similar for CHPM and RGWC $(199 \pm 12.7 \mathrm{~g} / \mathrm{cow} /$ day $)$ but tended to be greater $(\mathrm{P}=0.081)$ than CHAM cows $(168 \pm 12.7$ $\mathrm{g} /$ cow/day; Table 1).

\section{Water balance and urination behaviour}

Replacing half the RGWC pasture DM allocation by weight with chicory (CHAM, CHPM) increased total water intake (TWI) by $21.1 \mathrm{l} / \mathrm{cow} /$ day compared with the control RGWC ( $\mathrm{P}=0.043$; Table 2). Differences in 
TWI were due to the low DM\% of chicory (Table1) and, hence, greater feed water intake (FWI), which accounted for 76,78 and $64 \%$ of TWI for cows on
CHAM, CHPM and RGWC, respectively. As with TWI, daily urine volume was greater by $20.2 \mathrm{l} / \mathrm{cow} /$ day for those offered chicory (CHAM, CHPM) compared

Table 1 Feed composition, estimated dry matter intake (DMl; kg/cow per day of DM), nitrogen (N) intake, spot urine composition and faecal $\mathrm{N}$ concentration from cows offered chicory and ryegrass/white clover.

\begin{tabular}{|c|c|c|c|c|c|}
\hline Items & CHAM $^{1}$ & CHPM $^{1}$ & RGWC1 $^{1}$ & SEM $^{4}$ & $P$ value \\
\hline Herbage DM (\% FW) & $11.9^{\mathrm{c}}$ & $13.5^{\mathrm{b}}$ & $20.9^{a}$ & 0.54 & $<0.001$ \\
\hline Herbage CP (\% DM) & $14.6^{\mathrm{b}}$ & $12.7^{\mathrm{c}}$ & $15.8^{a}$ & 0.64 & $<0.001$ \\
\hline Herbage NSC (\% DM) & $40.1^{\mathrm{b}}$ & $45.4^{\mathrm{a}}$ & $26.1^{\mathrm{c}}$ & 1.15 & $<0.001$ \\
\hline Ratio of NSC:CP2 & $2.75^{\mathrm{b}}$ & $3.57^{\mathrm{a}}$ & $1.65^{c}$ & 0.89 & $<0.001$ \\
\hline Chicory intake & 9.00 & 9.31 & - & 0.57 & 0.578 \\
\hline Ryegrass/white clover intake & $7.34^{b}$ & $6.81^{b}$ & $16.6^{\mathrm{a}}$ & 0.23 & $<0.001$ \\
\hline Total dry matter intake & 16.3 & 16.1 & 16.6 & 0.25 & 0.122 \\
\hline Nitrogen intake (g/cow/day) & 646 & 556 & 667 & 36.5 & 0.151 \\
\hline Milk urea $(\mathrm{mmol} / \mathrm{l})$ & $3.08^{\mathrm{b}}$ & $3.39^{b}$ & $4.08^{\mathrm{a}}$ & 0.11 & $<0.001$ \\
\hline Milk urea nitrogen $(\mathrm{mmol} / \mathrm{l})$ & $6.16^{\mathrm{b}}$ & $6.77^{\mathrm{b}}$ & $8.15^{\mathrm{a}}$ & 0.22 & $<0.001$ \\
\hline Milk N output (g/cow/day) & $127^{\mathrm{a}}$ & $129^{a}$ & $115^{\mathrm{b}}$ & 3.14 & $<0.001$ \\
\hline $\mathrm{N}$ use efficiency (g/g N eaten) & $0.19^{b}$ & $0.24^{\mathrm{a}}$ & $0.17^{b}$ & 0.89 & 0.025 \\
\hline Urine $N(g / l)$ & $3.6^{b}$ & $3.8^{b}$ & $5.5^{\mathrm{a}}$ & 0.3 & $<0.001$ \\
\hline Urine Urea (mmol/l) & $77.9^{b}$ & $89.6^{b}$ & $139^{a}$ & 7.52 & $<0.001$ \\
\hline Urine $\mathrm{NH}_{3}(\mathrm{mmol} / \mathrm{l})$ & $0.70^{\mathrm{b}}$ & $0.73^{b}$ & $1.32^{\mathrm{a}}$ & 0.12 & 0.001 \\
\hline Creatinine $(\mathrm{mmol} / \mathrm{l})$ & $1.65^{\mathrm{b}}$ & $1.65^{\mathrm{b}}$ & $2.14^{\mathrm{a}}$ & 0.15 & 0.030 \\
\hline Urine $\mathrm{N}$ output (g/cow/day) ${ }^{3}$ & 168 & 198 & 200 & 12.7 & 0.081 \\
\hline Faecal N (g/kg DM) & 31.8 & 31.3 & 30.2 & 1.12 & 0.583 \\
\hline
\end{tabular}

${ }^{a-c}$ Means within a row with different superscripts differ $(P<0.05)$.

1 RGWC = perennial ryegrass/white clover only;

$\mathrm{CHAM}=$ ryegrass/white clover + morning allocation of chicory;

$\mathrm{CHPM}=$ ryegrass/white clover + afternoon allocation of chicory;

$2 \mathrm{NSC}=$ non-structural carbohydrates $=(100-(\mathrm{NDF}+\mathrm{CP}+\mathrm{Fat}+\mathrm{Ash}))$; $\mathrm{CP}=$ crude protein

3 Total daily urinary nitrogen (UN) output was estimated based on UN concentration from 4 hourly spot samples and total urine volume of the 4 hours preceding the spot sampling on days 6 and 9 . Average UN and faecal $\mathrm{N}$ concentrations were derived from spot samples collected from all 36 cows post morning and afternoon milking.

$4 \mathrm{SEM}=$ standard error of the mean.

Table 2 Means of variables used for estimating water balance in cows offered chicory and ryegrass/white clover.

\begin{tabular}{|c|c|c|c|c|c|}
\hline Item & CHAM $^{1}$ & CHPM $^{1}$ & RGWC1 & SEM $^{2}$ & $P$ value \\
\hline \multicolumn{6}{|l|}{ Water intake } \\
\hline from troughs (I/cow/day) & $28.4^{\mathrm{b}}$ & $25.1^{\mathrm{b}}$ & $35.9^{\mathrm{a}}$ & 1.17 & $<0.001$ \\
\hline from feed (l/cow/day) & $92.2^{\mathrm{a}}$ & $91.3^{a}$ & $62.3^{\mathrm{b}}$ & 3.79 & 0.008 \\
\hline Total water intake (I/cow/day) & $121.0^{\mathrm{a}}$ & $117.1^{\mathrm{a}}$ & $98.1^{\mathrm{b}}$ & 3.63 & 0.043 \\
\hline Water in milk (I/cow/day) & $18.1^{\mathrm{a}}$ & $18.9^{\mathrm{a}}$ & $17.2^{\mathrm{b}}$ & 0.48 & 0.001 \\
\hline Urine volume per event & 3.14 & 2.91 & 2.95 & 0.31 & 0.710 \\
\hline Urination frequency per day (events/cow/day) & $15.7^{\mathrm{a}}$ & $17.7^{\mathrm{a}}$ & $9.9^{b}$ & 1.12 & $<0.001$ \\
\hline Time between urination events (min) & $92.4^{\mathrm{b}}$ & $92.2^{b}$ & $144.1^{\mathrm{a}}$ & 8.42 & $<0.001$ \\
\hline Urine volume per day (I/cow/day) & $48.5^{a}$ & $48.1^{a}$ & $28.1^{\mathrm{b}}$ & 3.11 & $<0.001$ \\
\hline Faecal DM (g/kg DM) & 88.9 & 87.8 & 85.5 & 1.7 & 0.690 \\
\hline
\end{tabular}

${ }^{a-b}$ Means within a row with different superscripts differ $(P<0.05)$.

RGWC = perennial ryegrass/white clover only;

$\mathrm{CHAM}=$ ryegrass/white clover + morning allocation of chicory;

$\mathrm{CHPM}=$ ryegrass/white clover + afternoon allocation of chicory

2 SEM = Standard error of the mean. 

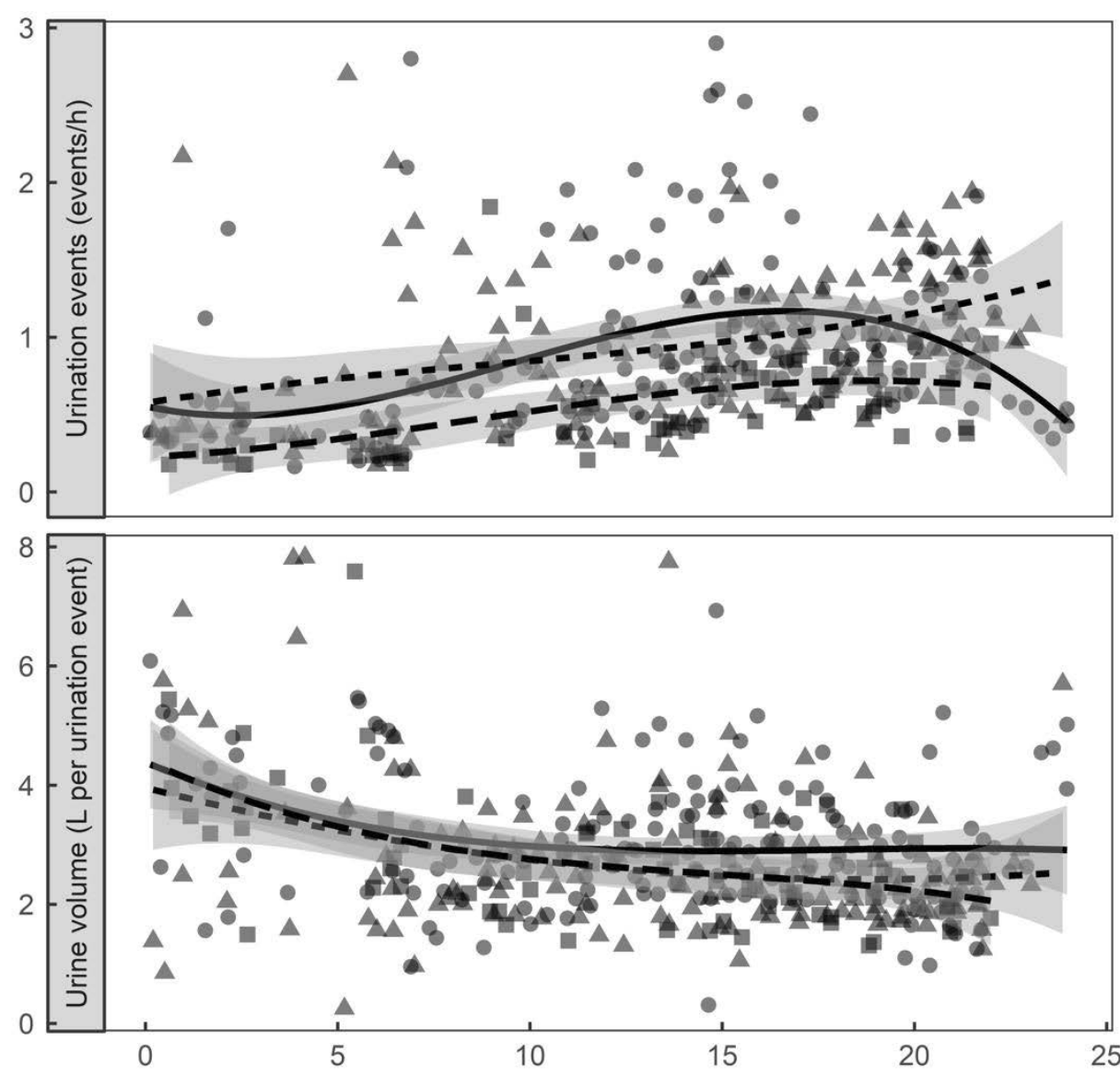

Hour of the Day

Figure 1 Diurnal variation of urination events per hour and urine volume as influenced by feeding regime. Square points and long dashed line points denote RGWC (perennial ryegrass/white clover only), triangle points and solid line denote CHAM (ryegrass/white clover + morning allocation of chicory) while circle points and short dashed denote CHPM (ryegrass/ white clover + afternoon allocation of chicory). Each point represents a single urination event.

with those offered RGWC ( $\mathrm{P}<0.001)$.

Urine volume per event ranged between $0.25-7.81$ per urination event (Figure 1), with an average of 3.00 $\pm 0.3 \mathrm{l} /$ cow/event (Table 2; $\mathrm{P}=0.71$ ). Feeding chicory increased urination frequency, averaging (mean \pm standard error of the mean) $15.7,17.7$ and $9.9 \pm 1.12$ events/cow/day for those receiving CHAM, CHPM and RGWC, respectively $(\mathrm{P}<0.001)$. Faecal DM content was not different between treatments, averaging $87.4 \mathrm{~g} /$ $\mathrm{kg} \mathrm{DM}$ across treatments.

Urinary $\mathrm{N}$ concentration was lower for cows offered chicory and, when combined with volume per event, resulted in a mean $\mathrm{N}$ load of $11.8,12.1,20.0 \pm 1.4 \mathrm{~g} \mathrm{~N} /$ urination event $(\mathrm{P}<0.001)$ for cows on CHAM, CHPM and RGWC treatments, respectively. There was no effect of forage treatment on faecal $\mathrm{N}$ concentration, which averaged $31.1 \mathrm{~g} / \mathrm{kg} \mathrm{DM}(\mathrm{P}=0.69)$ across treatments.
The diurnal pattern of urination intensity was similar among diets, with more urination events during intensive grazing bouts. However, the increase in urination events during intensive grazing was more pronounced when cows grazed chicory (Figure 1).

To highlight the diurnal divergence in urination patterns of cows grazing chicory from standard RGWC pastures, the relative frequency of urination was plotted against a RGWC as the 0 control (Figure 2). Feeding chicory in the afternoon increased urination events by nearly $39 \%$ between $0800-1200 \mathrm{~h}(0.50$ vs. 0.36 events/cow/h), and by $71 \%$, between $2000-2400$ h compared with cows offered RGWC (1.2 vs. 0.71 events/cow/h; Figure 2). On the other hand, feeding chicory in the morning increased urination frequency by $64 \%$ between 1200 and $1800 \mathrm{~h}(1.0$ vs. 0.61 events/ cow/h) when compared with cows offered RGWC.

Successive spot sampling of urine revealed lower 


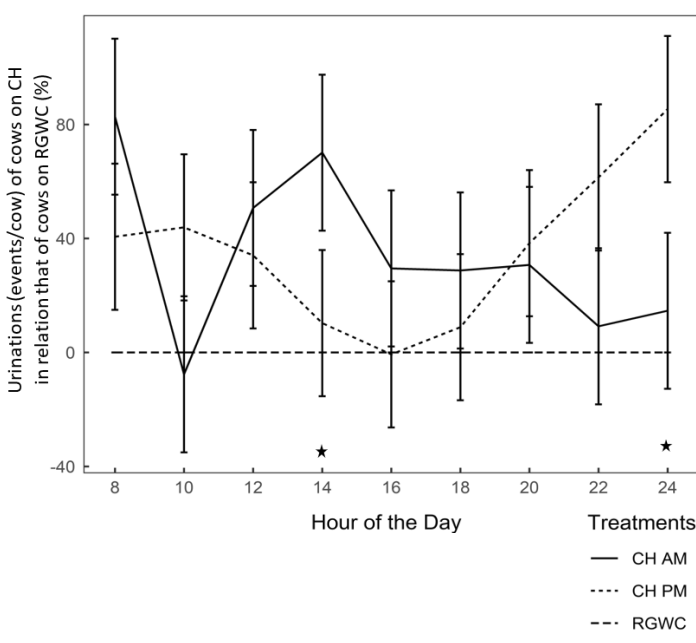

Figure 2 Effect of inclusion and time of allocation of chicory on urination frequency/cow averaged in $2 \mathrm{~h}$ intervals following allocation of fresh herbage at $\sim 0800$ and $1600 \mathrm{~h}$ in relation to urination frequency of the control cows measured at the same time of the day. Urination events of cows on RGWC only were set to $0 \%$. CHAM (ryegrass/white clover + morning allocation of chicory), CHPM (ryegrass/ white clover + afternoon allocation of chicory), RGWC (perennial ryegrass/white clover only). Solid lines denote CHAM, short-dashed lines denote CHPM, and long dashed line denote RGWC. Data are displayed as arithmetic means \pm standard deviation. The asterisks indicate tendencies at $P \leq 0.1$ between measurements made at the same time for cows fed CHAM vs CHPM.

UN concentrations in chicory fed cows compared to the RGWC group throughout the day (Figure 3). Due to similar urine volumes per urination event among treatments, urinary $\mathrm{N}$ load (g N/event) was greater throughout the day for the RGWC cows. The largest differences in $\mathrm{N}$ load occurred at $0400 \mathrm{~h}$ between CHPM and RGWC (8.4 vs. $29.6 \mathrm{~g} / \mathrm{l} \pm 2.62 \mathrm{~g}$ N/event; $\mathrm{P}=0.003$ ) and again at $1200 \mathrm{~h}$ with $41.5 \%$ greater $\mathrm{N}$ load from RGWC than chicory fed cows (14.7 vs. $20.8 \pm 2.62 \mathrm{~g} \mathrm{~N} /$ event; $\mathrm{P}<0.05)$. Cows offered CHAM tended to have lower $\mathrm{N}$ load than RGWC between 1600 and $2000 \mathrm{~h}(\mathrm{P} \leq 0.074)$.

\section{Discussion}

\section{Effect of forage type on water balance and urine $\mathrm{N}$ excretion}

The findings from this study support the hypothesis that UN concentration can be reduced by offering chicory as $50 \%$ of a grazed diet with RGWC herbage. The lower $\mathrm{UN}$ concentration due to chicory is in agreement with previous studies comparing chicory-based diets with the traditional RGWC diet fed to dairy cows (Minnee et al., 2017; Mangwe et al., 2019).
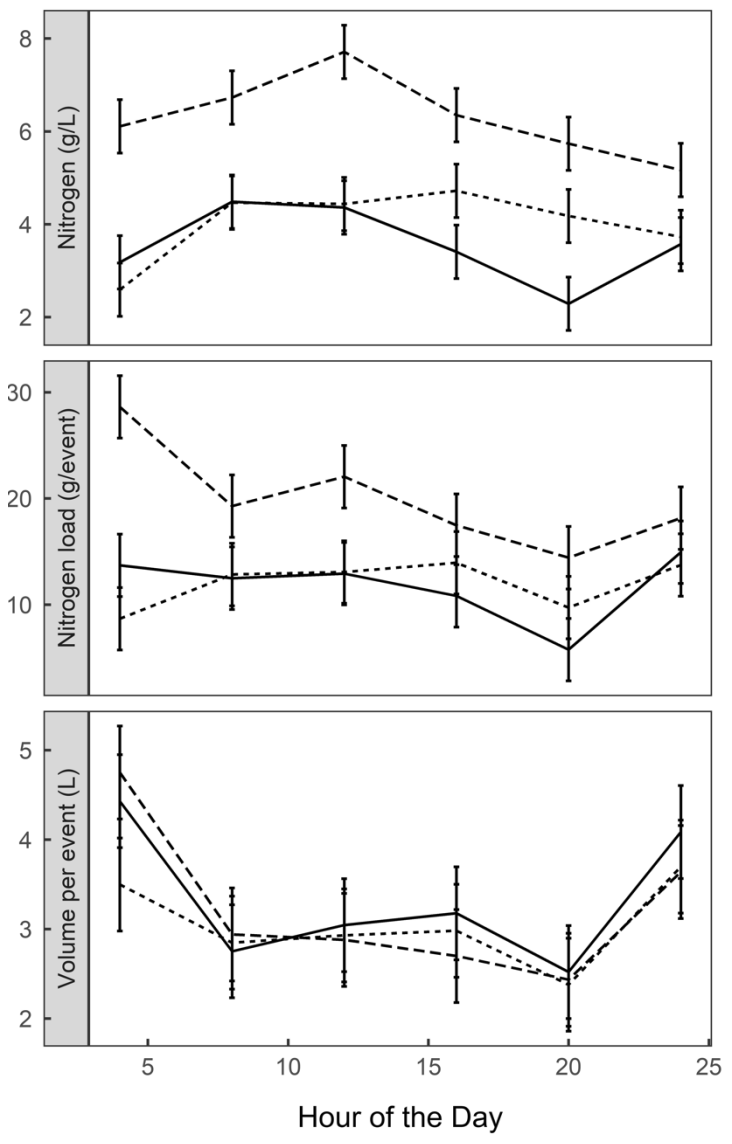

Figure 3 Diurnal variation of UN composition, urine volume per event and $\mathrm{N}$ load. CHAM = ryegrass $/$ white clover + morning allocation of chicory), CHPM = ryegrass $/$ white clover + afternoon allocation of chicory and RGWC perennial ryegrass/white clover only. Error bars are standard error of the mean $(n=3)$.

The decrease in UN concentrations and $\mathrm{N}$ load from cows offered chicory were likely due to increased water volume and increased urination frequency, resulting in diluted $\mathrm{N}$ content of the urine. Dilution of $\mathrm{UN}$ by increased urine water volume and increased urination frequency has been proposed as a means for reducing $\mathrm{N}$ loading to soils in cows offered chicory or plantain-based diets (Bryant et al., 2019). The increase in urination frequency for cows offered chicory diets observed here is consistent with earlier studies, which demonstrated that including chicory into the diet of dairy cows can alter urine excretion patterns (Mangwe et al., 2019). Because of the low DM content, cows on chicory consumed $20 \%$ more water compared with those on RGWC, which is likely to be the key driver behind increased urine volume (Murphy 1992). Coupled with the increased water content, chicory contains high mineral levels (including sodium and 
potassium), which earlier research indicated may play an important role in water excretion and extracellular homeostasis (Spek et al., 2012; Ledgard et al., 2015).

The extra urine and minerals excreted from cows fed chicory diets was distributed to pasture through more urination events, rather than via increased urine volume per event. Urination frequency increased from around 9.9 events/cow/day for those grazing RGWC to 16.7 events/cow/day for cows on chicory (CHAM, CHPM). Normal urination frequency for dairy cows is expected to fall between 9 and 15 urinations per day (Selbie et al., 2015). Further, the time between urinations was not constant as the current data showed that the density of urination events was greatest during and after grazing bouts. The pattern of events was reportedly similar, even for different forages, because of the association with grazing bouts and water intake as a result of grazing i.e. more urination events during higher activity (Aland et al., 2002; Draganova et al., 2016)for nitrogen $(\mathrm{N}$. The consistency and repeatability of the patterns of urination events observed for cows when offered chicory at different times of the day provides more information about the impact of high moisture feeds, such as chicory, on urine excretion. Using high moisture forages to increase urination frequency can be used in conjunction with other mitigation strategies to reduce UN load and excretion onto soils and into water courses.

Another explanation for the observed differences in $\mathrm{UN}$ concentration and $\mathrm{N}$ load may be the variation in $\mathrm{N}$ utilised for milk production. Nitrogen use efficiency was increased by approximately $29 \%$ in cows fed chicory diets than those fed the traditional RGWC diet only $(0.22 \mathrm{vs} 0.17 \mathrm{~g} / \mathrm{g} \mathrm{N}$ eaten). The improvements in NUE in cows fed chicory was supported by the lower concentration of MUN, a biomarker of the efficiency of milk production in lactating cows (Huhtanen et al., 2015). At similar apparent $\mathrm{N}$ intake, improvements in NUE for milk production and reductions in UN output suggest that $\mathrm{N}$ partitioning was altered in cows offered chicory, a similar premise previously offered by Totty et al. (2013) for cows consuming diverse diets containing chicory and plantain. Both chicory and plantain have a high ratio of NSC to CP than RGWC (Minnee et al., 2017), which, in this study, likely improved energy and protein supply to meet microbial requirements and improve milk protein yields (Mangwe et al., 2020). The CP content of chicory for CHAM and CHPM was unusually low at $14.6 \%$ and $12.7 \%$, respectively (Table 1) compared with common $\mathrm{CP}$ concentrations reported in New Zealand. Explanation for low protein of chicory during the study is likely due to prevalence of reproductive stem as a second-year crop, coupled with low $\mathrm{N}$ fertiliser used on the chicory pastures (Mangwe et al., 2020).
As urine volume per event was not affected by treatment, the use of chicory to reduce $\mathrm{N}$ load from urine can be estimated using equations developed by Selbie et al. (2015)relying on estimates of urine volume and $\mathrm{N}$ concentration, and the urine patch surface area, all of which are variable. Much is known about $\mathrm{N}$ cycling processes in the urine patch but further understanding of $\mathrm{N}$ loss, leaching of dissolved organic $\mathrm{N}$, and mineralization-immobilization turnover is needed. Typical values (as a percentage of the deposited urinary $\mathrm{N}$;

$\mathrm{UN}$ rate $\left(\mathrm{kg} \mathrm{UN} \mathrm{ha}^{-1}\right)=$ Conc $\left(\mathrm{g} \mathrm{UN} \mathrm{L}^{-1}\right) \frac{\mathrm{Vol}(\mathrm{L})}{\text { Area per urination event }\left(\mathrm{m}^{2}\right)} \times 10$

Assuming a urine column size of $5 \mathrm{~mm}$, the area per event $\left(\mathrm{m}^{2}\right)$ was calculated based on Romera et al. (2012) as;

Area per urination event $=\frac{\text { Average vol per event } \times \frac{1000}{10000}}{\text { Urine column } \times 0.1}$

This showed that the $\mathrm{N}$ load per ha for cows on chicory (CHAM, CHPM) would be $185 \mathrm{~kg} \mathrm{UN} / \mathrm{ha}$, which is $33 \%$ lower than the $285 \mathrm{~kg} \mathrm{UN} /$ ha predicted for cows on RGWC. The reduction of $\mathrm{N}$ load from cows offered chicory-based diets indicate the potential of this forage herb to reduce nitrate leaching.

\section{Effect of time of chicory allocation on UN excretion}

The second hypothesis related to the use of management to alter the $\mathrm{N}$ content of the herbage and balance the supply of energy and protein to the rumen. By allocating chicory in the afternoon and RGWC herbage in the morning, we were able to reduce herbage $\mathrm{CP}$ concentration and increase the ratio of NSC to CP. This was associated with greater NUE in CHPM than in CHAM and RGWC fed cows (Table 1) but did not appear to improve UN excretion characteristics. Counterintuitively offering chicory during the afternoon grazing tended to increase the estimated daily $\mathrm{UN}$ output $(\mathrm{g} / \mathrm{d} \mathrm{N}, \mathrm{P}=0.081)$ when compared with offering it in the morning. Because altering the timing of chicory allocation, by default shifts the timing of RGWC allocation, and the current results suggest that the timing of a new RGWC allocation may be more important to reducing $\mathrm{N}$ loss than the timing of chicory allocation. Figure 3 depicts UN concentration declining in the afternoon for both RGWC and CHAM, while the UN concentration is elevated for CHPM. Temporal separation of the two forages may change the associative effects of the two feeds. In sheep, feeding chicory with ryegrass altered ingestive behaviour and increased rumen clearance rate of ryegrass (Nikerdorn et al., 2019). Feeding chicory before ryegrass may alter $\mathrm{N}$ dynamics in the rumen through changes in ingestion and rumination (Mangwe et al. 2020) or through the profile of physical particles, release of 
water and nutrients from one diet prior to ingestion of an alternative diet. This is supported by previous modelling which compared the effects of timing of allocation of plantain revealing that by feeding the high moisture forage in the morning, rumen outflow is increased making way for greater ingestion of RG in the afternoon when sugars are higher (Gregorini et al., 2018). Integration of alternative forages to reduce $\mathrm{N}$ losses should also consider the optimal method of feeding the forages to capture the benefits.

\section{Conclusions}

Overall, cows on chicory diets increased urination frequency and decreased the concentration of UN when compared with those on RGWC. Timing of chicory feeding affected the diurnal patterns of urination, with environmental benefits indicated by feeding chicory in the morning. The consistency and repeatability of the results observed for cows offered chicory provided more information about its impact on urination patterns and UN concentration. While farmers are encouraged to adopt mitigation strategies to reduce $\mathrm{UN}$ losses, there is value in offering a range of forage options. The results showed that low moistures forages, such as chicory, have the potential to reduce $\mathrm{N}$ leaching through changes in urination patterns and UN loading. Additional reductions in $\mathrm{N}$ losses may be achieved through grazing management.

\section{REFERENCES}

Aland A, Lidfors L, Ekesbo I. 2002. Diurnal distribution of dairy cow defecation and urination. Applied Animal Behaviour Science 78: 43-54. https://doi. org/10.1016/S0168-1591(02)00080-1

Bates D, Mächler M, Bolker BM, Walker SC. 2015. Fitting linear mixed-effects models using lme4. Journal of Statistical Software 67: 1-48. https:// arxiv.org/pdf/1406.5823.pdf

Box LA, edwards GR, bryant RH. 2017. Diurnal changes in the nutritive composition of four forage species at high and low $\mathrm{N}$ fertiliser. Journal of New Zealand Grasslands 79: 103-110. https://doi. org/10.33584/jnzg.2017.79.564

Bryant RH, Miller ME, Greenwood SL, Edwards GR. 2017. Milk yield and nitrogen excretion of dairy cows grazing binary and multispecies pastures. Grass and Forage Science 72: 806-817. https://doi. org $/ 10.1111 /$ gfs. 12274

Bryant RH, Snow VO, Shorten PR, Welten BG. 2019. Can alternative forages substantially reduce $\mathrm{N}$ leaching? findings from a review and associated modelling. New Zealand Journal of Agricultural Research 63: 3-28. https://doi.org/10.1080/0028823 3.2019.1680395

Draganova I, Yule I, Stevenson M, Betteridge K. 2016.
The effects of temporal and environmental factors on the urination behaviour of dairy cows using tracking and sensor technologies. Precision Agriculture 17: 407-420. https://doi.org/10.1007/s11119-015-94274

Gregorini P, Bryant RH, Beck MR, Edwards GR. 2018. Plantain: It is not only the dietary content, but also how we graze it. New Zealand Journal of Animal Science and Production 78: 151-156

Huhtanen P, Cabezas-Garcia EH, Krizsan SJ, Shingfield KJ. 2015. Evaluation of between-cow variation in milk urea and rumen ammonia nitrogen concentrations and the association with nitrogen utilization and diet digestibility in lactating cows. Journal of Dairy Science 98: 3182-3196. https://doi. org/10.3168/jds.2014-8215

Kebreab E, France J, Beever DE, Castillo AR. 2001. Nitrogen pollution by dairy cows and its mitigation by dietary manipulation. Nutrient Cycling in Agroecosystems 60:275-285. https://doi. org/10.1023/A:1012668109662

Ledgard SF, Welten B, Betteridge K. 2015. Salt as a mitigation option for decreasing nitrogen leaching losses from grazed pastures. Journal of the Science of Food and Agriculture 95: 3033-3040. https://doi. org/10.1002/jsfa.7179

Mangwe MC, Bryant RH, Beck MR, Beale N, Bunt C, Gregorini P. 2019. Forage herbs as an alternative to ryegrass-white clover to alter urination patterns in grazing dairy systems. Animal Feed Science and Technology 252: 11-22. https://doi.org/10.1016/j. anifeedsci.2019.04.001

Mangwe MC, Bryant RH, Gregorini P. 2020. Rumen Fermentation and fatty acid composition of milk of mid lactating dairy cows grazing chicory and ryegrass. Animals 10: 169-185. https://doi. org/10.3390/ani10010169

Mangwe MC, Bryant RH, Gregorini P. 2021. Effect of vernalisation on the diurnal changes in fatty acid profile and nutrient composition of chicory in response to defoliation frequency. New Zealand Journal of Agricultural Research. https://doi.org/10 $.1080 / 00288233.2020 .1866029$

Minneé EMK, Waghorn GC, Lee JM, Clark CEF. 2017. Including chicory or plantain in a perennial ryegrass/ white clover-based diet of dairy cattle in late lactation: feed intake, milk production and rumen digestion. Animal Feed Science and Technology. 227: 52-61. http://dx.doi.org/10.1016/j.anifeedsci.2017.03.008

Minnée EMK, Leacha CMT, Dalley DE. 2020. Substituting a pasture-based diet with plantain (Plantago lanceolata) reduces nitrogen excreted in urine from dairy cows in late lactation. Livestock Science 239: $104093 \quad$ https://doi.org/10.1016/j. livsci.2020.104093 
Murphy MR. 1992. Water Metabolism of Dairy Cattle. Journal of Dairy Science 75: 326-333. https://doi. org/10.3168/jds.S0022-0302(92)77768-6

Navarrete S, Kemp PD, Pain SJ, Back PJ. 2016. Bioactive compounds, aucubin and acteoside, inplantain (Plantago lanceolata L.) and their effect on in vitro rumen fermentation. Animal Feed Science and Technology. 222:158-167. https://doi. org/10.1016/j.anifeedsci.2016.10.008

Niderkorn V, Martin C, Bernard M, Le Morvan A, Rochette Y, Baumont R. Effect of increasing the proportion of chicory in forage-based diets on intake and digestion by sheep. Animal 13: 718-726. https:// doi.org/10.1017/S1751731118002185

Nkomboni D, Bryant RH, Edwards GR. 2021. Effect of increasing dietary proportion of plantain on milk production and nitrogen use of grazing dairy cows in late lactation. Animal Production Science 61: 770779. https://doi.org/10.1071/AN20440

R Core Team. 2018. R: A language and environment for statistical computing. R Foundation for Statistical Computing, Vienna, Austria. https://www.r-project.org. Romera AJ, Levy G, Beukes PC, Clark DA, Glassey CB. 2012. A urine patch framework to simulate nitrogen leaching on New Zealand dairy farms. Nutrient Cycling in Agroecosystems 92: 329-346. https://doi.org/10.1007/s10705-012-9493-1

Selbie DR, Buckthought LE, Shepherd MA. 2015. The challenge of the urine patch for managing nitrogen in grazed pasture systems. Advances in Agronomy 129: 229-292. https://doi.org/10.1016/ bs.agron.2014.09.004
Shepherd M. 2020. Recommendations for the implementation of plantain in Overseer. AgResearch Report RE450/2019/069.

Shepherd M, Shorten P, Costall D, Macdonald KA. 2017. Evaluation of urine excretion from dairy cows under two farm systems using urine sensors. Agriculture, Ecosystems and Environment 236: 285294. https://doi.org/10.1016/j.agee.2016.12.017

Spek JW, Bannink A, Gort G, Hendriks WH, Dijkstra J. 2012. Effect of sodium chloride intake on urine volume, urinary urea excretion, and milk urea concentration in lactating dairy cattle. Journal of Dairy Science 95: 7288-7298. https://doi. org/10.3168/jds.2012-5688

Talke H, Schubert G. 1965. Enzymatische Harnstoffbestimmung in Blut und Serum im optischen Test nach Warburg (Enzymatic determination of urea in blood and serum in the optical test according to Warburg). Journal of Molecular Medicine 43: 174-175. https://doi. org/10.1007/BF01484513

Totty VK, Greenwood SL, Bryant RH, Edwards GR. 2013. Nitrogen partitioning and milk production of dairy cows grazing simple and diverse pastures. Journal of Dairy Science 96: 141-149. https://doi. org/10.3168/jds.2012-5504

Wachendorf C, Taube F, Wachendorf M. 2005. Nitrogen leaching from ${ }^{15} \mathrm{~N}$ labelled cow urine and dung applied to grassland on a sandy soil. Nutrient Cycling in Agroecosystems 73:89-100. https://doi. org/10.1007/s10705-005-8313-2 